Davies, I. 2009, 'Alliances and Networks: Creating Success in the UK Fair Trade Market', Journal of Business Ethics, vol. 86, no. S1, pp. 109-126.

\title{
Alliances and Networks: Creating Success in the UK Fair Trade Market
}

\author{
Dr. lain A. Davies \\ Cranfield University School of Management \\ Cranfield University \\ Cranfield \\ Bedfordshire \\ MK43 0AL \\ Tel: +44 (0) 1234751122 ext. 2575 \\ Fax: +44 (0) 1234751806 \\ Email: iain.davies@cranfield.ac.uk
}

Iain A. Davies - is a Research Fellow in Marketing at Cranfield University. He has a $\mathrm{PhD}$ in strategy and implementation from the International Centre for Corporate Social Responsibility at Nottingham University. He has well over 10 years experience working in and researching fair trade and has previously published in the Journal of Business Ethics, Corporate Governance, and Business Ethics: A European Review in this area. His research interests include social entrepreneurship, business-to-business networking and strategic account management. 


\section{Alliances and Networks: Creating Success in the UK Fair Trade Market}

\subsection{Abstract}

Data from a longitudinal study into the key management success factors the fair trade industry, provides insights into the essential nature of inter-organisational alliances and networks in creating the profitable and growing fair trade market in the UK. Drawing on three case studies and extensive industry interviews, we provide an interpretive perspective on the organisational relationships and business networks, and the way in which these have engendered success for UK fair trade companies. Three types of benefit are derived from the networks, Competitive Developments through virtual integration the organisations remain flexible and small whilst projecting size to the market, Intellectual Developments through the sharing of intellectual capital with a diverse network of organisations in many fields, and Ideological Developments through an Ideological Network of like minded individuals the companies can protect themselves from the assimilation of the original purpose of fair trade, to help the developing world. However, relative success at leveraging these benefits is influenced by three managerial factors, Partner Choice, Partner Use and Partner Management.

\subsection{Key Words}

Fair trade

Commercialisation

Alliances and networks

Ideology

\subsection{Introduction}

The fair trade movement sprang from a desire to encourage community development in some of the most deprived areas of the world (Brown, 1993). Fair trade is achieved through the "application, monitoring and enforcement of a fair trade supply agreement 
and code of conduct typically verified by an independent social auditing system" (Crane and Matten, 2004: p.333). Despite its public perception of being almost like a charity (Mintel, 2004), many fair trade organisations are, in-fact, profit seeking organisations (Davies and Crane, 2003, Moore, 2004). Similarly brands are now aimed at targeting mainstream customer groups and compete head-to-head for shelf space with major retail brands (Low and Davenport, 2006; Moore, 2004; Nichols and Opal, 2005; Wilkinson, 2007). Therefore despite distribution of profits (and supply chains) differing from many businesses within their markets the processes of marketing, sales and logistics are, in principle, identical to other small, social entrepreneurial start up companies (see Mair, Robinson and Hockerts, 2006; Davies, 2007).

This paper investigates the importance of inter-organisational alliances and networks in creating the profitable and growing fair trade market in the UK. Drawing on three case studies, data from longitudinal participant observation, interviews and secondary sources provide an interpretive perspective on the organisational relationships and business networks. Focusing on the benefits that accrue from networked partnerships, not the structure of these partnerships, the contribution of this paper is to bring the importance of these networks to the fore in future fair trade discussions. This research uncovers that alliances and inter-company networks have been purposefully embedded in the fair trade industry since its modern foundations. As such the success of the fair trade companies in the UK has been heavily influenced by the network and support infrastructures created within the companies. This has formed the bedrock of the competitiveness of the case companies and partially explains how these small businesses have been able to compete and take market share from businesses 
hundreds of times there size in mature markets such as coffees and count-line chocolate. This should be identified in further research as one of the main drivers for business development in fair trade.

The cases produce six key findings, three related to company benefits from networks (developments) and three factors affecting the success of company development (see figure 1 for summary). The developmental findings relate to the competitive development - locating and leveraging competitive capabilities of partners, intellectual development - learning from partners and sharing information of mutual benefit and ideological development - building a network of companies with similar ideologies and missions that can assist in supporting the long term pervasiveness of the company's ideology in the face of competitive pressure. The factors affecting success of the developmental agenda pivot around three key issues relating to: partner choice - How the case organisation identify the appropriate partners to leverage all three developmental benefits, partner use - looks at the differing approaches to the act of leveraging the most out of partners and partner management - looking at the ethos of how to manage the partners for maximum benefit to the organisation in the long term.

[Figure 1 about here]

\subsection{The importance of inter-firm networks}

Gomes-Casseres (1996) suggests that strategic alliances and social networks form the backbone of the modern competitive arena. "Firms in the course of their business activities establish a variety of inter-firm ties. Such ties include buyer-supplier relationships, strategic alliances, and joint memberships in industry associations, amongst others. These ties enable firms to exchange a variety of information, 
knowledge, and other forms of capital" (Koka and Prescott, 2002: p.796). A growing body of literature focuses attention on alliances and networks as a vital source of information necessary to maintain a competitive advantage (Ahuja, 2000; Burt, 1992; 1997; Dyer, 1997). Research into inter-firm relationships indicates that close partnerships can aid in developing and absorbing technology (Ahuja, 1998; Powell et al., 1996); reacting to environmental change (Miner, Amburgey and Stearns, 1990); reducing transaction costs (Dyer, 1997); and improving profitability (Baum et al., 2000).

Social network analysis / theory has emerged to identify and discuss the forms, structures and benefits of networks and alliances (Scott, 1992; Wasserman and Faust, 1994). Similarly, social capital has emerged to describe the intangible assets rooted in network relationships (Adler and Kwon, 2002; Inkpen and Tsang, 2005; Koka and Prescott, 2002; Leana and Van Buren, 1999; Nahapiet and Ghoshal, 1998). Through these theories we find networks providing a solid foundation and competitive advantage / differentiation for all types of organisations. In particular we see that networks are considered to have the greatest level of impact on organizational success and survival amongst entrepreneurial small and medium sized organizations (BarNir and Smith, 2002, Florin, Lubatkin and Schulze, 2003; Spencer and Schmidpeter, 2003; Walker et al, 1997), entrepreneurs themselves (Witt, 2004, Uzzi, 1997) and social enterprises (Leadbeater, 1997), all of which could easily apply to the majority of fair trade organisations. Yet to date our knowledge about the formation of networks, importance to fair trade organisations and the use made of them within any form of social enterprise is as yet limited. 


\subsection{Fair trade and networks}

The small market size and lack of public knowledge until recent years made fair trade merely of passing comment in academic writings and text books (McIntosh, et al., 1998). Recent growth has produced a much wider scope of consideration covering areas such as the market scope and growth (Moore, 2004; Nichols and Opal, 2005, Reynolds, 2000; Renard, 2003), tourism (Cleverdon and Kalisch 2000), consumerism (Strong, 1997), marketing (Tallontire, 2000) and social auditing systems (Dey, 2000; 2003). There has, however, been an increasing interest in the commercialisation or mass-marketing of fair trade (Davies and Crane, 2003; Moore, 2004; Golding and Peattie, 2005; Hira and Ferrie, 2006), driven by the advent of "fair trade companies" (Davies, 2007). Which are organisations that developed through the 1990's and 2000 's to spearhead the emergence of fair trade into the mainstream.

Prior to the emergence of "fair trade companies" a significant number of organisations involved in fair trade were non-profit seeking (charities and Alternative Trading Organisations (ATO's)), largely voluntary workforces and guided by philanthropic aims of increasing awareness of poverty (Nichols and Opal, 2005) and demonstrating solidarity with developing world producers (Tallontire, 2000). However, since the advent of fair trade labelling an increasing number of professional (non-voluntary), profit-seeking organisations have emerged carrying fair trade marks on products including "fair trade branders" (often mainstream brands offering a fair trade product as an extension to existing brand portfolio's - e.g. Nestlé, Fyffes), "fair trade adopters" (often formally organics companies adopting some fair trade brands and principles - e.g. Green and Blacks, Clipper) and "fair trade companies" (those that were either set up to be fair trade organisations or make fair trade the reason for the 
organisations existence - e.g. Cafédirect, Agro-fair). For a full discussion of these different types of organisations see Davies (2007).

This research focuses specifically on "fair trade companies" who were founded with an explicit fair trade agenda / ideology to undertake the logistics and marketing of lines of fair trade commodity products at a profit. These organisations were set up (often by the charities and ATO's mentioned above) with the dual purpose of:

1. increasing sales volume / profit and

2. the ideological foundation (shared by many fair trade organisations including those in this study) based on two principles:

a. Having close relationships with fair trade licensed, developing world producers and assisting in their growth through higher prices and community projects

b. Influencing change in the current market system to improve conditions and income across the entire market

(Davies, 2007)

In the mainstreaming literature, the intention of the fair trade companies is identified as having shifted from targeting consumers based on purely ethical reasoning to a broader focus on branding and quality (Low and Davenport, 2006; Moore, 2004; Nichols and Opal, 2005; Wilkinson, 2007). As part of this we also see a shift in ethical decision-making as commercial pressure to sell more volume (purpose 1) impinges upon the ideological purpose (purpose 2) of the fair trade companies (Davies and Crane, 2003). Therefore there is conflict between the two organisational purposes and in this paper networks are shown to assist in achieving mutuality between the two purposes. 
Networks have received only scant consideration in the fair trade literature to date. Auroi (2004), Lyon (2007), Maloni and Brown (2006) and Tallontire (2000) discussed the supply chain network structures between a fair trade company and their growing communities, Reynolds (2002) and Renard (1999) use networks to analyse the value chain within fair trade, and Nichols and Opal (2005) used social network theory as a method of analysing the way in which fair trade has communicated with the market and provide a structural review of the industry. However none of these works has explored the extent to which inter-firm networks have formed the basis of the competitive fair trade company, discussed the benefits accrued by fair trade companies from their networks or identified how these networks are managed.

\subsection{Networks in Social Enterprises}

The duel purpose of fair trade companies mean they can clearly be framed in terms of social entrepreneurs / social enterprises, which although not having a single definitive definition (Mair, Robinson and Hockerts, 2006) can be understood as led by private individuals, focused on raising awareness of issues of general public interest (Waddock and Post, 1991) to "exploit social innovation with an entrepreneurial mindset and a strong need for achievement" (Perrini and Vurro, 2006).

Leadbeater (1997) identified a social entrepreneur's networks as being one of their core assets in achieving both financial and social missions and Waddock and Post (1991) identify their social entrepreneurs' heavy entrenchment in networks being one of the driving factors for success. However little research in social enterprise has looked in-depth at how organisations use network and alliances to their advantage and 
Mair, Robinson and Hockerts (2006) specifically call for research investigating "Networks - Can the characteristics of social networks influence the sustainability of social entrepreneurial ventures?" [p.12], something we believe this paper begins to address

\subsection{Methodology}

Many papers on fair trade are normative (Moore, 2004; Reynolds, 2002; McDonagh, 2002) and the few which are empirical cover a range of topics from outside of the organisational context, for example Strong (1996, 1997) and Bird and Hughes (1997). Although, useful for gaining a broad understanding of the organisations, distance research leads to little contextual understanding. The research in this paper, in line with Dey (2003) and Randall (2005), is attempting to uncover the contextualised nature of organisational reality in fair trade companies. To this end no prior hypothesis was set but a broad research question of how are fair trade companies managed and how do they implement strategies and what impacts their success?

The aim of this research is to provide new insight in an area of literature currently lacking empirical research and deep contextual understanding so research had to be conducted through an unstructured approach (Miles and Huberman, 1994). The research was therefore designed to allow themes and nuances to emerge from the research data (Glaser, 1992). This involves developing rich contextual understanding and is an inductive research design. 


\subsubsection{Data Collection and Analysis}

Since the objective of this study was related to the internal dynamics of the companies it was important to develop a methodology suited to gaining the interpretations of those within the context and as such those individuals within the organisations. This is achieved by focusing on getting as close as possible to the world of what is under study and interpret this world and its problems from the inside (Dyer and Wilkins, 1991). A case study approach was therefore selected as the principle method of locating this in-depth information.

Case study based methods are predominantly used in inductive research (Yin, 1994) and for research from an interpretivist paradigm (Hassard, 1993). Data sources can be wide ranging, including not only primary qualitative data, but reports, secondary data, even statistics and surveys if they provide information of relevance to the study (Goulding, 2001). Nevertheless, the methods of enquiry were, predominantly qualitative to gain a rich contextual understanding (Mintzberg, 1979; Van Maanan, 1979).

Sampling of case studies is crucial, as the choice of sample influences the results of a study (Miles and Huberman, 1994). At the commencement of this longitudinal study there was a limited selection of companies engaged in the commercial, mass-market approach to fair trade. In fact only 20 UK organisations had signed a fair-trade licensing agreement of which most were not fair trade but organics companies or charities. The interest of this research however was on the future direction of the industry and therefore wanted to focus on what appeared at the time, and proved during the research, to be the enduring form of fair trade in the market - fair trade 
companies. The UK was the most advanced and highest value market for fair trade products and had a greater number of these enterprises, so proved the natural choice for research location. Four companies were contacted for participant observation and interview based research designs of which three agreed. One of which later decided to only participate in interviews due to market pressure (Table 1 provides the essential data on these companies).

\section{[Table 1 about here]}

To ensure internal validity and reliability, a constant comparative method borrowed from grounded theory (Barnes, 1996) was utilised, where responses from multiple people within the same organisation were compared against each other, field notes and secondary sources. For this to be successful it was important to interpret the data outputs and abstract underlying rationales from them, to promote contextual understanding grounded in the data (Rubin and Rubin, 1995). This involved harnessing research methods to collect data conducive with an inductive design in such a way as to allow theories to emerge from it (Eisenhardt, 1989). External validity and reliability was increased through triangulation with both secondary sources and substantiate interviews with appropriate third parties (such as network partners). This led to 12 further interviews.

Analysis was carried out through an inductive process using the tools developed for analysing grounded theory research as synthesised by Spiggle (1994). Interviews were transcribed and run through a series of categorisation, abstraction, and comparison processes to identify themes which were then placed into dimensions to aid in 
integration into theory. These tentative theories could then be reviewed iteratively to decide on the direction of future data collection and then a period of refutation was undertaken where emergent theories were put to participants for review. Inconsistencies or extensions indicated by participants have been incorporated into this final version of the paper. However, producing a general theory was not the focus of this study, but rather the opportunity was taken to develop a rich picture of contextual understanding in the fair trade companies, in order to contribute new insights to the development of theory.

\subsection{Key Importance of Networks}

Fair trade companies were founded with two purposes, the sales volume / profit purpose and the ideological purpose. These purposes are similarly reflected in the missions of the case organisations (summary in Table 1). At times conflict exists between the two different purposes as outlined in Davies and Crane (2003). However alliances and networks have proved valuable to assisting the companies to achieve both purposes and it is this we investigate.

The networks provide developmental benefits to the case organisations through three ways, competitive development (purpose 1), intellectual development (purpose 1) and

ideological development (purpose 2). However the benefits received from the networks are tempered by three factors, partner choice, partner use and partner management. Through this paper we look at each of these benefits and factors in turn.

\subsubsection{Competitive development}

The ability to form and maintain a multitude of successful relationships has been a key driving force behind the rapid growth of fair trade in the United Kingdom. Be 
those relationships with other fair trade institutions, journalists to gain significant press coverage or multinational corporations to gain shelf space for what were fundamentally niche products, networks have been an influential driver of the case companies' success. This has also occurred in mature and concentrated markets with limited numbers of multinationals controlling significant proportions of the market (coffee, tea and chocolate). In this section we review some of the key structural relationships that have been necessary to ensure the companies fast growth in these saturated markets. Through this we investigate the networks of ownership, the way in which fair trade companies act fundamentally as virtual integrated firms (Weiner, Nohria, Hickman, and Smith, 1997; Magretta, 1998) in the networked supply chain and the networked distribution of their products.

Networked ownership - Some fair trade companies were founded in non-traditional ways, making extensive use of networks of owners. These networks of owners enabled the fledgling companies to take advantage of the unique competencies of these new owners. An example of networked ownership is Cafédirect where four organisations joined competencies together to produce arguably the most successful fair trade product in the world.

\footnotetext{
"[Equal Exchanges] contribution to Cafédirect was that [they] were the only [founding] member who had any marketing experience. Twin [Trading] had the coffee supply chain management, Oxfam had campaigners and Traidcraft had Traidcraft reps.” (EE1, Former Cafédirect Director).
}

At the time all four organisations had a shared interest in fair trade but independently did not have the power to drive fair trade out of its alternative trading history and begin the trend of the mainstreaming of fair trade (Moore, 2004). However through 
combining their different competencies they were able to create a stronger competitive proposition and drive growth and profit in the companies.

This original idea of combining competencies and developing new companies was repeated with the foundation of Day where again Twin Trading (Twin), with partners The Body Shop and grower co-operative Kuapa Kokoo started the company as a joint venture, this time harnessing Twin's supply chain management, The Body Shops marketing capability and Kuapa Kokoo's produce. Again success was achieved, and then again with fair trade company, Agro-fair, three years later.

Producing a network of owners with a combined interest in fair trade has therefore been seen as a particularly valuable method of providing new start-ups with the necessary competitive positioning. This has been based on combining the networks with a mix of the competitive competencies that the companies will need during its early stage of formation.

Networked Supply Chain - In addition to the foundation of companies, the way in which the fair trade companies' supply chains are structured also shows this dependence on alliances and networks. For instance, all three of the companies are principally marketing and logistics companies (although Equal Exchange has begun some importation of products). They do not import, manufacture or package their own brands. This has allowed them to take advantage of some economies of scale despite being small organisations with limited volumes.

"The relationship with Weinrich (the manufacture) was important because we did not have the volumes, equipment or finance to undertake manufacture. ... but they also make chocolate for the German fair trade company Gepa. So they already had fair trade 
experience which is a big plus because it meant that they were already into the supply

chain for fair trade cocoa" (DC2)

However, working with these established companies also allowed them to ensure higher quality and better product consistency than earlier fair trade products were able to achieve.

Cafédirect are a great example of the virtual organisation as they are the $6^{\text {th }}$ biggest coffee brand in the UK yet have less than 40 employees. Twin act as an importer and supply chain manager for most of Cafédirect's coffee, Keith Spicer manufacture, package and distribute their teas, whereas Gala, roast grind, package and distribute their coffees. This leave Cafédirect the ability to remain small and entirely marketing and logistics focused. It has meant that the companies could appear to the market as a much larger organisation than they were through the use of existing business links to market. This has given them greater credibility and market impact despite only being small, new start up businesses.

Networked distribution and retailing - In fact, on top of supply chain virtual integration, distribution is also only partly done by the organisations (see Cafédirect example) as they often use wholesalers and specialist distributors. Equal Exchange distribute almost entirely through wholesalers. Even the products they distribute through mail order are delivered to the company headquarters by wholesaler Green City. However, we see the fair trade organisations beginning to work together to leverage the existing networks to assist future growth and development. In particular this is visible at Equal Exchange where their existing network into the wholefood market allows them to act as a distributor for both Day and Cafédirect. This has given 
Day and Cafédirect access to a difficult market without having to build their own relationships.

We see Day and Cafédirect using this same technique in other market sectors too where they use specialist distributors to enter markets with high barriers to entry. For example, Cafédirect have a partnership with Coffee Fresh for vending machine distribution and had an agreement with Costa Coffee to ensure distribution in the burgeoning market for coffee shops. Day similarly have an agreement with Jenks for distribution into the independent retail market.

"We were finding breaking into the independent retailers incredibly difficult because

Nestlé, Mars and Cadbury's have agreements with many of the shops not to sell competing products... Jenks are a distributor who can get us into that market.” (DC5)

This not only shows using networks to break down market barriers but also demonstrates the companies outsourcing operational functions to gain a better footing in the market, and allowing them to specialise in the logistic and marketing of their products.

This is exemplified in the relationship between Day and The Co-operative Retail Group (CRG- interviewee code CO). Day began a venture with CRG, to produce the first own label chocolate bar by a supermarket in the UK.

\footnotetext{
"The Co-op have moved from being a customer to a partner... this is especially evident if you look at the [Co-op] annual report." (DC8) - (The CRG annual report for 2003 has a picture of the joint brands as the focal point of the front cover.)
}

Through this Day hold the fair trade licence and the product is supplied from their supply chain network, but the bar is branded as CRG Own-label. This gave Day access to extensive shelf space in CRG's more than 2,000 stores across the UK, and 
prevented a competing product from entering the UK market. As such Day has begun to use networks build its own barriers to entry and protect its own market share from similar products. The success of this strategy has been borne out through its reuse with Sainsbury's and Starbucks own-labels in the years following.

What the cases display is a propensity to focus on the marketing a logistics and using a network of other organisations to undertake the operational aspects of the company, as with virtual organisations. In principle, the fair trade companies own a licensed fair trade brand and are the hub through which a number of organisations interact in the production and development of a product. Even some marketing work has been outsourced to advertising agencies, graphic designers or the general public through volunteers and competitions. They seek partners with competencies which the organisation does not internally posses. What the case companies offer in return is a track record of successful and profitable network creation and automatic reputation benefits for partners not currently involved in fair trade, but wishing to create the appropriate capability. This has, to date, proved a profitable method of leveraging the fair trade label and maintaining high growth levels whilst keeping the companies small and flexible. Therefore networks throughout the value chain have provided strong support for the growth and profit portion of the companies' organisational purposes.

\subsubsection{Intellectual development}

In addition to the networked nature of the operational side of the business, the case companies use social networks to develop their market information and business knowledge capability. This was made clear in the following statement by DC8, "by forming business partnerships we are able to produce greater volumes of market 
information and significantly stronger brands". Transfer of information between partners has therefore been a primary influencer on the companies' success.

BarNir and Smith (2002) suggest that small organisations need to build strong social networks with other organisations to produce the significant levels of intellectual capital needed to remain competitive, especially in changing markets (Eisenhardt and Martin, 2000). This is especially relevant in fair trade as it moves from a charity based background to a more professional nature competing against dominant players in the market. Intellectual capital will be used as the term to describe the unique knowledge which cumulatively the individuals in an organisation possesses and the information gained from network partners, therefore allowing the knowledge to be viewed as a resource and a type of capital as economists discuss human and physical capital (Nahapiet and Ghoshal, 1998). Intellectual capital is created by the manipulation of knowledge and information gained from a broad field of sources. In changing markets, such as fair trade, Grant (1996) and Kogut (1996) indicate the manipulation of wide-ranging, timely, relevant informational resources is critical. As such the creation of unique inter-firm alliances is promoted as an aid to providing important information for creating a competitive advantage, through sharing resources, knowledge and expertise (Dyer and Singh, 1998; Dyer, 1996; Hamel, 1991). The case organisations provide valuable insight into networking for mutual advantage in practice. We first divulge some of the benefits that accrue from trading partners but then focus in particular on the importance and intellectual capital from non-trading partners and forums and associations. 
Trading Partners - In addition to trading goods, many of the supply-chain and joint brand partners have a heavy influence on the case companies through the information they share about the competitive landscape and strategic future of fair trade. If we return again to the Day example of its relationship with CRG, Day was able to gain a great deal of business knowledge based on the relationship they had built.

"I think working with [CRG] has been good. I mean doing the bar with them has been a learning curve. Working with them has been useful but also dialogue with them has told us more about the retail sector. That's because none of us has come from food retail we needed to learn fast and so having people like that telling us that something is normal is [invaluable].” (DC1)

The intellectual capital gained from the relationship with CRG gave them a significant boost in their growth aspirations by providing them with valuable market knowledge. This gave them a stronger footing in the market and significantly improved their chances of getting the future "own-label" partners later on.

Equal Exchange similarly jointly branded products with Twin Trading and took on a significant joint venture with the formation of Cafédirect. Equal Exchange and Twin are very close partners - "Twin are our strongest allies in fair trade" (EE1) - sharing great volumes of information. Twin are Equal Exchange's biggest coffee supplier and ran a joint brand, however they contact each other regularly, representing a united front on the board of Cafédirect. The extensive relationship has run for many years and according to respondents, the trust levels between them are exceptionally high.

\footnotetext{
"Without Twin I am not sure we could have survived this long. We are good friends and can discuss anything together... They are not afraid to say they don't agree with us on something and will do whatever is in their power to help us when we need it." (EE3)
}

The sharing of information has provided both organisations with valuable intellectual capital, especially in locating supply chains. It has also provided commercial 
opportunities and a gateway to relationships with further organisations (such as through Cafédirect). However sharing intellectual capital through trading relationships is only part of the story. The high importance of intellectual capital transfer is most significantly viewed when there is no value chain necessity for the relationship to exist but for the information that can be shared.

Non-trading partners - Having relationships with little or no trading, but simply social networking, is a common feature in the organisations and indicates that some value must be attained through the intellectual capital which is imparted. Individuals in the case organisations have a number of social contacts, who are in working situations that can produce valuable intellectual capital. For example, EE1 and EE5 have maintained very close relations with Equal Exchange America. Although historically only linked by Equal Exchange UK borrowing the name in the early 1980 's, the companies have visited one another and "shared ideas on the future of fair trade for a number of years" (EE3). EE5 also went on visits with the members of Equal Exchange America to meet a Mexican growing co-operative, which supplies some of the companies' raw materials, thus openly displaying the bond between the organisations.

Christian Aid is one of the main information partners for Day. The organisations have worked together from the foundation of Day and continue to do so. Christian aid has over 200,000 members and over 35,000 active campaigners. The relationship has led to an initiative called 'Choc Shop', where Christian Aid supporters sell chocolate to friends and family. Christian Aid has also aided Day in dealing with the press and designing campaigns since they have a large core competence in this area. The 
influence has also extended to them holding a seat on the board of directors with direct input into top level decisions. The closeness of the partnership has provided strength to the decision-making and sales of the fair trade produce.

Day also joined with Comic Relief to promote both the Dubble Chocolate Bar and fair trade education in schools. Day gained a great deal of free publicity from the relationship e.g. the free sponsorship of Celebrity Big Brother 1 (BT paid 40 million pounds to sponsor Big Brother series two only months later). However, the biggest benefit for Day was to be associated with Comic Relief, giving the company a great deal of public acceptance. The relationship, however, also provides a wealth of intellectual capital because of the size and scope of Comic Relief means they have a broad range of people from many disciplines with a wide knowledge base. Purely informational partnerships extend the network structure, offering the spread and depth of information more wide reaching than through purely trade based relationships.

The Body Shop is the third owner and has a distinct ethical pedigree in the general publics conscious. It is perceived by respondents to offer a number of commercial advantages for Day.

"Body Shop has been a great support to us. It has a world-wide reputation and it also has, a media team: an unequalled team that give us support and advice. That has been very good. With a company that has a similar ethical basis so it was not just getting ideals from anywhere but from someone with similar goals." (DC1)

Body Shop provided financial support, buying airtime to show television adverts for the Divine bar when it was first released in 1998 and offered extensive legal advice. The intellectual capital a successful commercial company like The Body Shop can offer a small start up company is considered invaluable to the success of the enterprise. 
Forums and Associations - Fair trade associations; such as EFTA (European Fair Trade Association), and co-operative workers associations are forums for information sharing amongst the communities involved. EE5 sits on some of these committees and can gain information from sources as diverse as politicians to clergymen. DC8 for one also was regularly interactive on the Fairtrade Towns Discussion group where many issues throughout the whole of fair trade get discussed. The broad range of people and sources of data, which can be gained from such committees and communities, is a key source for network partners, market and consumer preferences.

At Cafédirect we see a similar drive to be involved in forums and associations to build the levels of intellectual capital and engage stakeholders. Three organisations in particular provide and important insight into the importance of these relationships and these are:

- The Producer Conference - which provides an opportunity for Cafédirect employees, Twin Trading (the importer) employees and the growers (the supplier) to meet to "develop collective strategies and responses to challenges in the market" (Cafédirect, 2003)

- The Pioneers' Forum - which is a network for companies who want to embed values in their working practices

- The Friends of Cafédirect (FOCD) - which is a network of consumers interested in the future of the company, they also hold one non-executive directorship to protect the customers' interests.

The use of forums and associations gives the companies an ability to tap into the knowledge and ideas held by parties with a mutual interest in the furtherance of the 
business. In the case of FOCD it also ensures that Cafédirect stay in close contact with their customers to ensure they continue to provide what they require.

\subsubsection{Ideological development}

Fair trade organisations often come together; as with the formation of Cafédirect, to give any new companies an initial boost within fair trade but then enclave (Mintzberg, 1983, 1989) the company. By enclave we refer to forming a subsidiary or clone of an organisation then separating completely to allow the new organisations to be entirely independent. In fair trade these enclaved companies go on to help the next generation of companies to emerge ${ }^{1}$.

From the creation of companies and the continual enclaving fair trade has formed an interconnected network, which this paper refers to as the "ideological network", of organisations pursuing similar goals in relation to improving living conditions in the developing world (purpose 2). Figure 2 shows a simplified ideological network for Twin Trading. Through enclaving Twin has developed a range of organisations for which it is co-founder and owner. These organisational joint ventures, such as Day, Cafédirect and AgroFair, have provided links to other well established organisations, such as Oxfam, Traidcraft and The Body Shop, who Twin have been able to rely upon to fill competency gaps in its business practice for further subsidiary production. Twin is fundamentally a supply chain facilitator and lacks the commercial and marketing skills required to promote mass-market products. However, through developing the networks with other companies (such as Oxfam etc.) with similar purposes in relation to the developing world, they can produce significantly stronger business propositions

\footnotetext{
${ }^{1}$ Day chocolate a fairly recent enclave of Twin and Sister company to Café Direct have helped AgroFair by promoting their new products in the Day Chocolate supporter pamphlet which is mailed to over 3000 fairtrade supporters. Equal Exchange offered distribution support to Day as they themselves started.
} 
but hold onto their ideological purpose. This forms the ideological network where a peer group is established to ensure continuation of the ideological purpose in the face of increased commercialisation, but also provide a focal point for the shared resources amongst the network participants.

\section{[Figure 2 about here]}

As the enclaved organisations have grown and begun to develop further network relationships, there has been a strong tendency to work with organisations with similar ideological values, such as Comic Relief, Christian Aid, CRG, Equal Exchange America etc. This has led to further expansion of organisations in the expanded ideological network. This network then provides a strong cultural influence within the organisations, as employees meet and work with disparate groups of individuals all sharing the common ideological purpose (purpose 2).

In turn the strong cultural influence and ties through the ideological network create increased opportunity to work together as one solid networked unit to produce unified communication to the customer and leverage each other brand propositions without diluting each organisations own purpose.

[When we started out] we wanted to sell something that people wanted to buy and have a message on that. A campaign message that things have to change and that all the power was with the brands. All the producers did was grow the coffee, there was no manufacturing, no marketing, no branding. All of that power was with multinationals, so all the economic benefits of trade were almost entirely in the hands of those with the capital. Now that critique is still true, there has been no change. However [what] we have discovered since then is that it is 
very difficult to change institutions. It is much easier to work with partners and build a strong partnership organisation [that] can have influence (EE1)

The focus on working collectively to pursue the united goal of aiding the developing world gives considerable empowerment to what, individually are relatively insignificant organisations. The collective influence, at times like Fairtrade Fortnight (through the ideological network) can provide a much greater exposure for fair trade and through presenting a united front, has led to vast increases in public awareness of developing world trade and social issues. That allows the individuals more leverage to approach further organisations.

Large corporations, or charities, provide vital outlets and marketing knowledge to the case companies. By working within larger organisations, such as Comic Relief and CRG, Day has vastly increased brand recognition and sales. With Equal Exchange working closely with Twin and the joint venture with founding Cafédirect, furthered there espoused mission considerably. The ideological network has therefore formed a backbone to a more successful fair trade in general. The network has gone a long way towards maintaining the original core values of fair trade, even though the companies have moved a considerable distance from the volunteer or campaigning organisations where the movement was founded. The network, as a whole, makes changing the policies of larger organisations more likely since it can make the fair trade movement appear considerably larger than it actually is (representing less than $1 \%$ on average of the sales in its respective markets).

As an extended part of the ideological network, the motivation inspired by meeting farmers has been a common theme in all fair trade companies. In Davies and Crane 
(2003) grower visits were identified as increasing cognitive proximity between growers and decision-makers ensuring a higher moral intensity towards grower issues. This is born out in the ideological network where the growers form a fundamental linkage between the organisations and their use in aligning employee's values. Grower visits form a focal point for members of different fair trade companies to come together and immerse themselves in discussions about fair trade ideology with "evidence" of its success in the form of a grower to bolster the belief in the worth of the initiative. This has promoted a perpetuation of consideration for the developing world in most decisions, even as staff have changed and trading circumstances have led to increased co-operation with none fair trade companies.

Looking deeper into the network relationships between Day, Cafédirect, Equal Exchange, Twin, Oxfam, Christian Aid, and many other organisation, form a band of people with similar end goals to what they do, even if their methods differ somewhat. The networks apparently produces a clear guiding force in the continuation of values and principles in the main case organisations, preventing assimilation of the values in the face of commercial pressure. Juxtaposed to the limiting affect the ideological network can have on assimilation, the network itself can aid in changing other organisations policy, as with Comic Relief. Formally based only in fund raising, by linking with Day the charity began to take a greater interest in aligning the benefits of trade-not-aid in improving livelihoods in underdeveloped countries.

The forming of an ideological network in fair trade is important to the success of blending the two conflicting purposes of fair trade companies. Commercial pressures influence decisions such as whom and how to work with partners. Davies and Crane 
(2003) demonstrate how this pressure is creating more conflict between the ideological purpose of the companies and the original purpose as put in place by the founders. However by having a network of organisations all sharing to some extent the ideological purpose, the companies are able to maintain a peer group and sounding board for conflicting decisions. It also provides the opportunity to share success stories and inter-relate to growers to keep the moral intensity high for employees. Additionally however, it gives access for skills and resources that would otherwise be rare which can assist in the competitive positioning of the companies, and also by working together gives the market the impression that fair trade is in fact much bigger than it, in reality, is.

\subsection{Factors Affecting Success}

In the previous section we identified how important networks have been in producing the success in fair trade companies in the UK, from both a competitive basis and an ideological basis. Each of the case companies however has had differing levels of success and as such three key limiting factors have been identified which impact upon the success of the company development from networking, Partner Choice, Partner Use and Partner Management.

\subsubsection{Partner Choice}

Networks are built progressively over a number of years. The data above exposes a range of network partners and the different styles of association that have developed in the fair trade companies. What the cases display is a propensity for these fair trade organisations to seek partners with competencies which the organisation does not internally posses. Day learnt about the food industry from CRG, gained advertising expertise from Body Shop and wholesale distribution from Equal Exchange. Day has 
also moved from trying to supply direct to independent outlets after they found it increasingly difficult to gain shelf space with smaller shops. Jenks (a food distribution agent) were therefore brought in as a distribution partner. Similar examples are available throughout the case companies and more broadly in fair trade. In the reverse the fair trade companies have offered the ability for their partners to develop a brand or affiliation with a popular social movement (fair trade) and increased "credibility" (CO2) with the market place. Therefore the ability to identify organisations with competencies the company does not already possess, but are valuable to the market place is a key factor in successfully achieving the purposes. However, beyond this there is a fundamental desire in fair trade organisations to work with organisations that have a similar developmental agenda.

Core values are a recurring theme in partner selection, especially for Day and Equal Exchange. Comic Relief and Christian Aid developed a relationship with Day because of the shared values of aiding the underdeveloped world. The wording of values concerned with aiding the third world on all three organisations websites are almost identical, following closely the work standards proposed by the Fairtrade Foundation. Similarly, the principle reason given for the relationship between Day and CRG was that CRG "demonstrated a commitment to fair trade over a number of years" (DC2). "I think you need to think like you share some values... [the relationship] has been a very nice partnership and you can trust them because you want the same thing" (DC1). Corporate value systems therefore impact upon partner selection for Day. Equal Exchange similarly chose specifically to work extensively with Green City Wholesalers, because they were a co-operative venture, the same as Equal Exchange. Similar justification was given for working with Cafédirect, Twin, One World Shops 
Oxfam and many more. The benefit of maintaining strong relationships with other cooperative or fair trade-affiliated companies is important and valuable in the ideological network. As EE1 and DC1 suggest, it maintains trust, which can aid in reducing the companies risk, allowing them to get on with the company's mission.

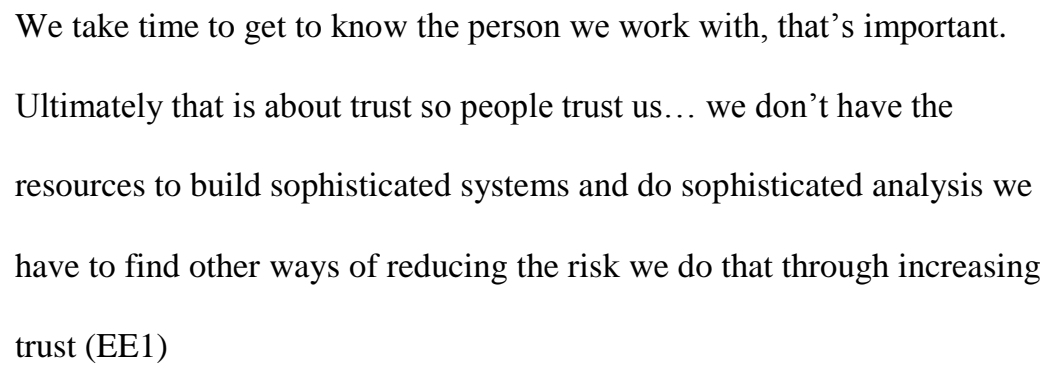

This view is supported by Uzzi (1996) who commented on trust being an informal measure of relationship control (see below). The research also suggests that, working with organisations with similar values, not only increases trust, but also has a lower perceived level of risk. The case companies, therefore, spend much of their daily duties maintaining and building relationships rather than selling products. Sales are believed to be the result of successful trusting relationships.

In the reverse internal values as a vehicle for encouraging network partners to work with the case organisations is apparent. Sainsbury's, CRG and Starbucks chose to work with Day because it offered considerable credibility to the own labelled product. Channel 4 similarly agreed, when requested by Comic Relief (traditionally a BBC venture), to waive the sponsorship fee for Celebrity Big Brother, because they wished to be associated with helping fair trade. Mounting academic support exists to promote that partners are more willing to co-operate in business relationships; either alliances or information sharing, with organisations whom they have developed a mutual trust (Fukuyama, 1995; Putnam, 1993). The data offers strong support for this proposition for example the longevity of Equal Exchanges relationship with Green City has led to 
increasing levels of communication and information sharing between the organisations.

Partner choice is therefore a vital influencing factor in creating successful networks. The companies must search out partners who fulfil competency gaps, yet this is tempered by the companies' preference to work with partners with similar ideological values. Placing too much emphasis on the competitive edge can lead to others in the ideological network questioning the values of the companies (this has to some extent happened with Cafédirect and rumours were rife in 2003 that they may drop the fair trade mark), whereas in the converse too much focus on the values of partners can lead to lost opportunities which could have helped grow the business (this has happened with Equal Exchange repeatedly such as refusing to work with supermarkets vastly limiting growth, and picking IT consultants based of fair trade standing rather than technical competence).

\subsubsection{Partner Use}

The case companies work with disparate groups and often network with companies not necessarily associated with the actual market the case organisation is competing in. We find partners providing unexpected information and services to the company such as charities providing PR support, supermarkets and wholesalers providing strategic support and retailers providing market information.

\footnotetext{
"Without the knowledge and expertise of the wholesalers and their willingness to share that with us we would not be able to remain competitive, we don't have the resources" EE1
} 
"Christian Aid have been great support, they have a great PR team and that has been valuable" DC4

"We have to leverage the relationships we have got, if a contact gives us a marketing outlet we have to capitalise on that" CD3

Being able to leverage the most out of partners and to a certain extent exploit advantageous positions is a principle determinant in the relative performance levels of the case companies and forms the third limiting factor of company development through networks.

Cafédirect is far more likely to leverage an advantageous position than either of the other two companies, and Equal Exchange is the least likely to take an action regarding leverage. For Equal Exchange the principle reason for this is their goal of demonstrating an alternative way of trading, manifests itself as viewing exploiting partners as a typically "traditional" method of business and they do not want partners to feel exploited. Whereas with goals based on increasing volume of sales to improve the developing world, Cafédirect identify leveraging skills and competencies in partners as a fundamental process in growth and it is the shared purpose and commercial success which binds their networks together, rather than friendship. In principle therefore the willingness to take advantage of opportunities to leverage network partners capabilities, even if intuitively abstract, can be a key limiting feature of company development through networks.

\subsubsection{Partner Management}

How to manage networks has received some academic consideration (Dyer, 1997; Dyer and Singh, 1998; Kostova and Roth, 2003; Uzzi, 1996). Once partners have 
been developed the case companies work at managing the relationship to gain the most out of it. Dyer and Singh (1998) distinguish between two styles of network/alliance management: third party enforcement and self-enforcement. Third party enforcement indicates an external controlling body, such as a legal contract, which role is generally fulfilled by the FLO and Fairtrade Foundation through the Fairtrade Mark maintaining relationships with reputable supply chains. Beyond supply chains however, self-enforcement has been conducted by the organisations themselves. Cafédirect have been making the move towards contracting the founding companies to fulfil their distribution and advertising roles for Cafédirect products. This formalised method has, however, received considerable opposition from the founders, who consider the former trust relationships to be adequate. Day and Equal Exchange have, because of their more trust based network management ideals used less abrasive network management techniques.

Alternatively to the contractual methods of management, self-enforcement leads to both formal and informal mechanisms. The formal mechanisms, such as financial or investment hostages (Williamson, 1983), rely on gaining control of joint assets to align economic incentives to maintain the relationship. This is visible in Days relationships in joint ventures with CRG, Sainsbury's and Starbucks, and also offering board seats to maintain close ties with Comic Relief and Christian Aid. These methods ensure long term relationships by giving the partner a stake in the success of the company. Effective management of networks, however, could involve many different forms of incentive above and beyond hostages, but relative success of each is under conceptualised. 
Informal self enforcement is common, especially in Equal Exchange. Informal incentives; trust (Uzzi, 1996), goodwill (Powell, 1990) and reputation (Larson, 1991), are flexible but of greater risk than financial hostages. As mentioned above, Uzzi (1996) discussed trust as an informal control within a relationship, indicating that partners you trust are less likely to take opportunistic advantage. This is evidenced through Equal Exchanges relationships across the board. As EE1 commented above, they use trust as a tool, through being open with partners, there is a mutual acceptance of some level of obligation to uphold that trust. Yet there is inherent risk in this as

\section{EE3 comments}

I think that [the business] cannot be [built] on relationships alone. I mean you've got to have the other issues addressed. It's just the technical stuff that is missing and you can buy these skills in. So [a relationship is] not a strength on its own, it's not sufficiently enough, but our strength is, above and beyond all of those things, are the relationships. (EE3)

This over reliance on keeping partners happy rather than managing them has led to two problems. Firstly, Cafédirect have, in the eyes of EE2, abused the trust Equal Exchange have put in them by removing them from important decisions (Equal Exchange used to hold a board seat and were distributors for Cafédirect before Cafédirect bypassed them and supplied directly to Equal Exchanges Customers). Secondly, one product in particular had dramatically increased in cost and was not noticed until it caused considerable financial damage. This was down to too much effort being put into building trusting relationships that the simple things like costs were not being appropriately managed.

A further benefit of a track record of trust however is that is appears to encourage future potential network partners. This is seen in the relationship between Day and 
Equal Exchange, where Day's sister company, Cafédirect, had been distributing coffee through Equal Exchange for seven successful years and Equal Exchange had a record of minimising the cost for the company, therefore building trust. As such, Day decided that Equal Exchange were appropriate as their link to the wholesaler network.

Goodwill, in many ways, is associated with trust, since it is the trust which builds goodwill into the relationship. To an extent, goodwill and obligations can be seen when Day was offered the opportunity (as were Cafédirect) to supplying directly to SUMA Wholefoods (Equal Exchanged biggest customer for Day and Cafédirect products). Day, due to their goodwill for Equal Exchange, rejected SUMA, but when they did consider moving distribution they stated that they would pay a yearly fee to Equal Exchange for facilitating the relationship, even though there was no contractual agreement to do so.

Reputation of partners could also be valuable in maintaining the relationships. It is Days reputation as a fair trader which gained the partnerships with CRG and Sainsbury's. Now the joint brands are successful but in both cases the fairtrade licence for the product is held by Day, making it impossible for the supermarkets to continue the products without Day maintaining their position as a reputable fair trade organisation, representing another form of financial hostage. Reputations can therefore mean a lot to the future of relationships, but even once reputations gain the relationship, other forms of management can still be put into place.

What this tells us therefore is that informal mechanisms of relationship management have been the historical mainstay of fair trade networks. However, as the companies 
have become more commercialised the need for more formal mechanisms such as financial hostages becomes more important. Too heavy a reliance on trust and relationship building, as part of the management and competitive system, could prove difficult to manage and predict. Locke (1999) raised significant concerns about the objectivity of business people, who may promote significant levels of network relationships, failing in their duty to the organisation by letting opportunities pass in favour of maintaining a close partnership. For Equal Exchange, the formation of relationships is fundamental to the business objective of demonstrating alternative trading relationships, but they have at times risked the survival of the company by failing to take care of the simple things within there own organisations in the pursuit of stronger relationships, or by refusing to formalise relationships to provide themselves protection from the fickle nature of transactional relationships.

\subsection{Conclusions}

There had been little consideration of the benefits accrued to fair trade companies or social entrepreneurs from the formation of networks in the existing literature. Investigating fair trade without understanding the importance of network benefits within the industry reduces the contextual accuracy of that understanding due to the pervasiveness and competitive importance of networks and the benefits accrued from them. The first and boldest contribution of this paper is to suggest that without successful network creation and management fair trade would not exist in the form it does today in the UK. Networks have not only been key to the creation of the branded fair trade companies, markets access and marketing, but also key to the physical production of the products. 
In this paper it is demonstrated how fair trade companies (as distinct from fair trade ATOs) have two over-riding purposes, to sell more volume of fair trade at a profit and to demonstrate support for developing world producers by educating the consumer, paying higher prices, getting involved in community projects and identifying perceived inadequacies in the market mechanism. These two purposes are often in conflict and networks are a principle tool used in blending and achieving both purposes in the face of conflict.

Networks improve sales and profitability by allowing fair trade companies to be virtually integrated and allow the organisations' to appear much larger than they are to the marketplace. They also allow the companies to pool information from a breadth of fields of knowledge without having to employ specialist from each field and improve competitiveness, thus satisfying purpose 1 . The importance these networked benefits have had on fair trade had not previously been explored in the literature to a great extent and this paper identifies these benefits as being fundamental to the growth and competitive success of fair trade in the UK.

However, by creating a network / peer group of companies that share the same ideological purpose of assisting the developing world, not only is the scope for trusted partners increased and pool of sharable skills expanded but there is a sounding board and ideological support network to ensure commercial pressures do not undermine the ideological purpose of fair trade in the companies. Thus the ideological network is a new theoretical contribution not only to fair trade companies but could be of significant importance in the practical application of other ideologically based initiatives moving forwards. 
However, the success of the fair trade companies differs in respect to the extent they have been able to leverage the networks to meet the purposes of the company. This has been due to three limiting factors on success, partner choice, partner use and partner management. This provides a solid contextual basis for understanding variance in benefits accrued for network association and provides greater insight into the management of networks within fair trade, also lacking from existing literature.

This research has provided a sound basis for understanding the importance of networks in UK fair trade. This is important for other countries following in the footsteps of UK fair trade and moving towards high levels of commercial approaches to dealing with typically aid based social initiatives. The empirical contribution of this paper has been to provide evidence of the importance of networks in both fair trade and other small organisations but also to provide a theoretical basis for understanding fair trade competitiveness into the future. In particular there is a theoretical contribution in relation to the creation of ideological networks for both ideological perpetuation and as a method of business growth in none traditional marketplaces.

Although this work was based principally on three case studies the findings are wholly relevant to most UK fair trade companies as found through the extensive research undertaken outside of the participant observation with similar importance given to networks in other organisation such as Traidcraft, AgroFair and Oxfam to name but three. However applicability also appears to hold for other none UK businesses such as Gepa and Equal Exchange America who rely heavily on networks and form parts of the extended networks investigated in this study. 
The extent to which these contributions provide insight for other social entrepreneurships is tentative without further research. Certainly it appears that ideological hierarchies should be a valuable network for perpetuation of ideology if given the time and credence necessary in the organisations to influence decisions. Working with larger organisations and virtually integrating would also appear to be a successful strategy to artificially appear bigger in the market place and sharing information with many partners appears a valuable way of informing decisions. However whether these would automatically provide growth and competitive success is questionable and therefore should only tentatively been seen to inform practical application of fair trade success factors.

Further research should identify the import role played by network partners in the creation of value in fair trade, but also the importance of issues such as the ideological network should be tested against other commercialised social issue related initiatives to gain an understanding of its relative value. More work should also be undertaken to measure the return on investment certain types of relationship have and identify the tipping point in the management of relationships where the resource investment begins to provide lesser returns.

\subsection{References}

Adler, P.S. \& Kwon S. W.: 2002, "Social capital: Prospects for a new concept", Academy of Management Review, 27: 17-40.

Ahuja G.: 2000, "The duality of collaborations: inducements and opportunities in the formation of interfirm linkages" Strategic Management Journal 21(3): 317343

Aurio, C.: 2004. "Improving sustainable chain management through Fair Trade." Greener Management International, 43: 25-35. 
Barnes, D.M.: 1996, "An analysis of the grounded theory method and the concept of culture", Qualitative Health Research, 6(3): 429-41.

BarNir, A. and Smith, K. A.: 2002, "Interfirm alliances in the small business: The role of social network" Journal of Small Business Management, 40(3): 219-232

Baum, J. A., Calabrese, C. T. \& Silverman, B.: 2000, "Don't go it alone: Alliance network composition and start-ups performance in Canadian biotechnology". Strategic Management Journal, 21: 267-294.

Bird, K. \& Hughes, D.: 1997, "Ethical consumerism: the case of "fairly-traded" coffee, Business Ethics: a European Review, 6(3):159-167

Brown, B. M.: 1993, Fair Trade, Zed Books Ltd, London

Burt R. S.: 1992, Structural Holes: The Social Structure of Competition. Harvard University Press: Cambridge, MA.

Burt R. S.: 1997, "The contingent value of social capital." Administrative Science Quarterly, 42: 339-365.

Cafédirect: 2003, www.cafedirect.co.uk, 12/8/00 - 17/08/04

Cleverdon, R. and Kalisch, A.: 2000, "Fair trade in tourism" International Journal of Tourism Research, 2(3): 171-187

Crane, A. and Matten, D.: 2004, Business Ethics. Oxford University Press: Oxford

Davies, I. A. and Crane, A.: 2003, "Ethical decision making in Fair Trade companies", Journal of Business Ethics, 45: 79-92

Davies, I. A.: 2007. "The eras and participants of fair trade: an industry structure/stakeholder perspective on the growth of the fair trade industry." Corporate Governance, 7(4): 455-470.

Dey, C.: 2000, "Bookkeeping and ethnography at Traidcraft Plc: A review of an experiment in social accounting" Social and Environmental Accounting Journal, 20(1): 16-19

Dey, C.: 2003, "Social accounting at Traidcraft Plc: An Ethnographic Study of a struggle for the meaning of fair trade" Working Paper, University of Dundee

Dyer J. H and Singh H.: 1998, "The relational view: cooperative strategies and sources of interorganizational competitive advantage" Academy of Management Review 23(4): 660-679.

Dyer J. H.: 1997, "Effective inter-firm collaboration: how firms minimize transaction costs and maximize transaction value" Strategic Management Journal 18(7): 535-556.

Dyer, J. H.: 1996, "Specialized supplier networks as a source of competitive advantage: Evidence from the auto industry" Strategic Management Journal, 17(4): 271-292

Dyer, W. G. and Wilkins, A. L.: 1991, "Better stories, not better constructs, to generate better theory: A rejoinder to Eisenhardt" Academy of Management Review 16(3): 613-619

Eisenhardt K. M. and Martin J.: 2000, "Dynamic capabilities: what are they?" Strategic Management Journal, 21(10\&11): 1105-1121

Eisenhardt, K. M.: 1989, "Building theories from case study research" Academy of Management Review, 14(4): 532-550

Florin, J., Lubatkin, M., \& Schulze, W.: 2003, “A social capital model of high-growth ventures", Academy of Management Journal, 46: 374-384.

Fukuyama, F.: 1995, Trust: The Social Virtues and the Creation of Prosperity, New York: Free Press

Glaser, B.: 1992, Basics of Grounded Theory Analysis: Emergence v Forcing, Mill Valley: The Sociology Press 
Golding, K. and Peattie, K.: 2005. "In search of a golden blend: Perspectives on the marketing of fair trade coffee", Sustainable Development, 13: 154-165

Goulding, C.: 2001, "Grounded theory: A magical formula or a potential nightmare" The Marketing Review, 2(1): 21-34

Grant, R. M.: 1996, "Towards a knowledge-based theory of the firm" Strategic Management Journal, SI 17: 109-122

Gulati R.: 1995, "Does familiarity breed trust? The implications of repeated ties for contractual choice in alliances" Academy of Management Journal 38: 85112

Hamel, G.: 1991, "Competition for competence in inter-partner learning within international strategic alliances" Strategic Management Journal, 12: 83-103

Hassard, J.: 1993, Sociology and Organisation Theory, Cambridge: University Press

Hira, A. and Ferrie, J., (2006) "Fair trade: Three key challenges for reaching the mainstream", Journal of Business Ethics, 63: 107-118

Inkpen, A. C. \& Tsang, E. W. K.: 2005, "Social capital, networks, and knowledge transfer", Academy of Management Review, 30: 146-165.

Kogut, B.: 1996, "What firms do? Co-ordination, identity, and learning" Organizational Science, 7(5): 502-521

Koka, R. B. and Prescott, J,: 2002, "Strategic alliances as social capital: A multidimensional view" Strategic Management Journal, 23(9): 795-816

Kostova, T. and Roth, K.: 2003, "Social capital in multinational corporations and a micro-macro model of its formation" Academy of Management Review, 28(2):297-317

Larson, A.: 1991, "Partner Networks: Leveraging external ties to improve entrepreneurial performance" Journal of Business Venturing, 6: 173-188

Leadbeater, C.: 1997. The Rise of the Social Entrepreneur. London: Demos.

Leana, C. R., \& Van Buren H. J., III.: 1999, "Organizational social capital and employment practices", Academy of Management Review, 24: 538-555.

Locke, E. A.: 1999, "Some reservations about social capital" Academy of Management Review, 24(1): 8-9

Low, W. and Davenport, E.: 2006. "Mainstreaming Fair Trade: Adoption, assimilation, appropriation." Journal of Strategic Marketing, 14(4): 315-328.

Lyon, S.: 2007. "Fair Trade Coffee and Human Rights in Guatemala." Journal of Consumer Policy, 30: 241-261.

Magretta, J.: 1998, "The power of virtual integration: An interview with Dell computers Michael Dell" Harvard Business Review, 76(2): 72-85

Mair, J., Robinson, J. and Hockerts, K.: 2006. Social Entrepreneurship. New York: Palgrave Macmillan.

Maloni, M. J. and Brown, M. E.: 2006. "Corporate Social Responsibility in the supply chain: An application in the food industry." Journal of Business Ethics, 68(1): 35-52.

McDonagh, P.: 2002, "Communicative campaigns to effect anti-slavery and fair trade: The case of Rugmark and Cafédirect" European Journal of Marketing, 36(5\&6): 642-667

McIntosh, M., Leipziger D., Jones K. and Coleman G.: 1998, Corporate Citizenship: Successful Strategies for Responsible Companies, London: FT Pitman.

Miles, M. B. and Huberman, A. M.: 1994, Qualitative Data Analysis: An Expanded Sourcebook $2^{\text {nd }}$ ed. Sage, London 
Miner, A. S, Amburgey, T. L. and Stearns, T. M.: 1990, "Interorganizational linkages and population dynamics: buffering and transformational shields", Administrative Science Quarterly. 35: 689-713.

Mintel,: 2004, Coffee - UK, Mintel International Group Limited:

Mintzberg, H.: 1979, "An emerging strategy of 'direct' research" Administrative Science Quarterly, 24: 582-589

Mintzberg, H.: 1983, Structure in fives: Designing effective organizations, London: Prentice Hall

Mintzberg, H.: 1989, Mintzberg on management: Inside our strange world of organisations, London: Free Press

Moore, G.: 2004, "The fair trade movement: parameters, issues and future research" Journal of business Ethics, 53 (1-2): p73

Nahapiet J, and Ghoshal S.: 1998, "Social capital, intellectual capital, and the organizational advantage" Academy of Management Review, 23: 242-266

Nicholls, A. and Opal, C.: 2005. Fair Trade: Market-Driven Ethical Consumption, London: Sage

Perrini, F. and Vurro, C.: 2006, "Social entrepreneurship: Innovation and social change across theory and practice." In Mair J. et al.. (Eds.) Social Entrepreneurship: 57-86. New York: Palgrave Macmillan.

Powell, W. W., Koput, K. W. and Smith-Doerr, L.: 1996, "Interorganizational collaboration and the locus of innovation: networks of learning in biotechnology" Administrative Science Quarterly, 41: 116-145

Powell, W. W.: 1990, "Neither market nor hierarchy: Network forms of organizations" in Staw, B. M. and Cummings, L. L. (eds.), 1990, Research in Organizational Behaviour Volume 12: 295-336, Greenwich CT: JAI Press

Putnam, R. D.: 1993, Making Democracy Work: Civic Traditions in Modern Italy, Princeton: Princeton University Press

Randall, D.C.: 2005, "An exploration of opportunities for the growth of the fair trade market: Three cases of craft organisations" Journal of Business Ethics, 56(1): 55:67

Renard, M. C.: 2003, "Fair trade: Quality, market and conventions", Journal of Rural Studies 19: 87-96.

Renard, M.C. 1999a. "The interstices of globalization: The example of fair coffee." Sociologia Ruralis, 39(4): 484-500.

Reynolds, L.: 2000, "Re-embedding global agriculture: the international organic and fair trade movements", Agriculture and human values, 17: 297-309

Reynolds, L.: 2002, "Consumer/producer links in fair trade coffee networks", Sociologia Ruralis, 42(4): 404-422

Rubin, H. J. and Rubin, I. S.: 1995, Qualitative Interviewing: The art of Hearing Data, Sage, London

Scott, J.: 1992, Social Network Analysis. Sage, Newbury Park CA.

Spence, L. J. \& Schmidpeter, R.: 2003. "SMEs, social capital and the common good", Journal of Business Ethics, 45: 93-108.

Spiggle, S.: 1994, "Analysis and interpretation of qualitative data in consumer research" Journal of Consumer Research, 21(3): 491-503

Strong, C.: 1996, "Feature contributing to the growth of ethical consumerism - A preliminary investigation" Marketing Intelligence \& Planning, 14(5): 5-13

Strong, C.: 1997, "The role of fair trade principles within sustainable development" Sustainable Development, 5: 1-10 
Tallontire, A.: 2000, "Partnerships in fair trade: reflections from a case study of Cafédirect" Development in Practice, 10(2): 166-177

Uzzi, B.: 1996, "The sources and consequences of embeddedness for the economic performance of organizations: the network effect" American Sociological Review 61: 674-698

Uzzi, B.: 1997, "Social structure and competition in interfirm networks: The paradox of embeddedness", Administrative Science Quarterly, 42: 35-67.

Van Maanen, J.: 1979 "The fact of fiction in organizational ethnography" Administrative Science Quarterly, 24: 539-550

Waddock, S. A. and Post, J. E.: 1991, "Social Entrepreneurs and Catalytic Change." Public Administration Review, 51(5): 393-401.

Walker, G., Kogut, B. and Shan, W.: 1997, "Social capital, structural holes and the formation of an industry network" Organization Science, 8(2): 109-125

Wasserman, S. and Faust, K.: 1994, Social Network Analysis. Cambridge University Press, Cambridge.

Weiner M., Nohria N., Hickman A., and Smith H.: 1997 "Value networks - The future of the U.S. electric utility industry", Sloan Management Review, 38(4): 21-34.

Wilkinson, J.: 2007, "Fair Trade: Dynamic and dilemmas of a market oriented global social movement." Journal of Consumer Policy, 30: 219-239 .

Williamson, O. E.: 1983, "Credible commitments: Using hostages to support exchanges" American Economic Review, 73: 519-535

Witt, P. 2004. "Entrepreneurs' networks and the success of start-ups" Entrepreneurship \& Regional Development, 16(5): 391 - 412.

Yin, R.: 1994, Case Study Research: Design and Methods, 2nd edition SAGE, London 


\section{Figure 1 - Networks - benefits and factors affecting success}
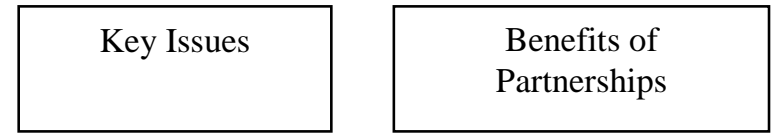

Factors affecting success basis of the competitive positioning of many modern fair trade companies

\section{Competitive} development

Intellectual development

Ideological development

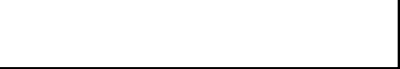

Partner Choice

Partner Use

Partner Management

Table 1: Company information

\begin{tabular}{|c|c|c|c|c|}
\hline Company & $\begin{array}{l}\text { Employees } \\
\text { over period }\end{array}$ & Access & Ideology & Use of Ideology \\
\hline $\begin{array}{l}\text { Equal } \\
\text { Exchange* }\end{array}$ & $5-8$ & $\begin{array}{l}2 \text { visits, } 5 \\
\text { weeks } \\
10 \text { interviews } \\
\text { (4 repeats) }\end{array}$ & $\begin{array}{l}\text { Demonstrate alternative trading } \\
\text { through relationships }\end{array}$ & Forms action \\
\hline $\begin{array}{l}\text { Cafédirect } \\
* *\end{array}$ & $20-30$ & $\begin{array}{l}2 \text { visit, } 3 \text { days } \\
7 \text { interviews }(2 \\
\text { repeats) }\end{array}$ & $\begin{array}{l}\text { Pioneer fair trade into mainstream to } \\
\text { maximize sales and Therefore grower } \\
\text { income }\end{array}$ & $\begin{array}{l}\text { Aids formulation } \\
\text { and } \\
\text { Justifies action }\end{array}$ \\
\hline Day**** & $10-12$ & $\begin{array}{l}3 \text { visits, } 7.5 \\
\text { weeks } \\
16 \text { interviews } \\
\text { (4 repeats) }\end{array}$ & $\begin{array}{l}\text { Demonstrate successful Alt. Trading to } \\
\text { drive change in cocoa industry and pass } \\
\text { profits back to Growers }\end{array}$ & $\begin{array}{l}\text { Aids Formulation } \\
\text { and } \\
\text { Justifies action }\end{array}$ \\
\hline
\end{tabular}

*Equal Exchange is a members Co-operative with a golden share held by Equal Exchange Charity (made up of all previous co-op members)

** Cafédirect was a joint venture between four organisations but is now a Public Limited Company with founders still owning $40 \%$ of the stock

*** Day Chocolate Company is a joint venture between Body Shop (15\%), Twin Trading (50\%) and Grower Co-operative Kuapa Kokoo (35\%) 
Figure 2 - Twin Trading's ideological hierarchy network

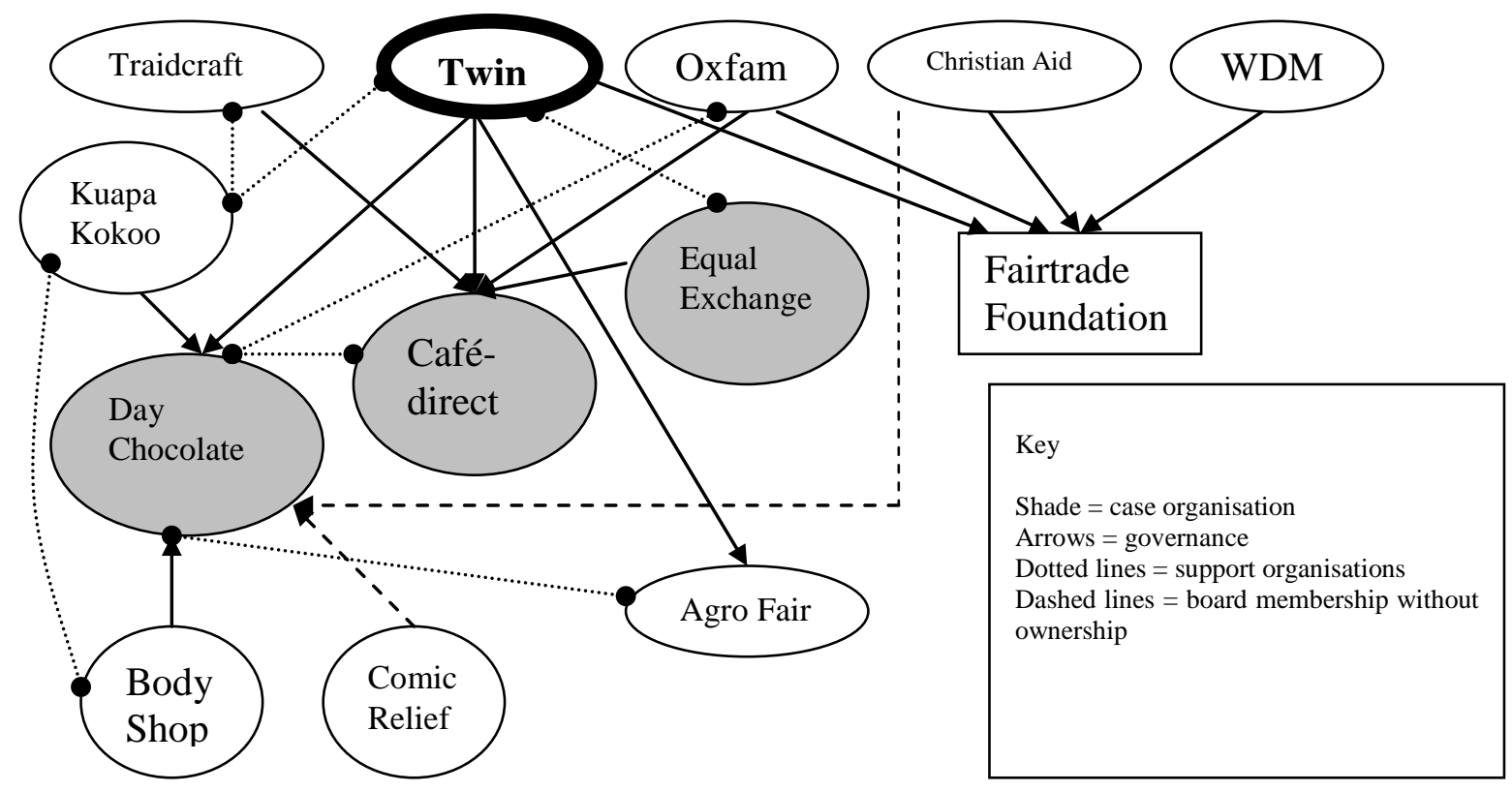

